\title{
СПЕЦІАЛЬНІ ОЗНАКИ СУБ'ЄКТА АДМІНІСТРАТИВНИХ ПРОСТУПКІВ НА АВТОМОБІЛЬНОМУ ТРАНСПОРТІ
}

Вступ. Обов'язковою умовою правильної кваліфікаціїадміністративного проступку є точне встановлення його суб'єкта, тобто конкретної особи, дії чи бездіяльність якої спричинили небезпеку суспільним відносинам, охоронюваним санкціями адміністративно-деліктних норм. Відсутність суб'єкта означає відсутність складу правопорушення в цілому. Більш того, без вірогідної інформації про суб'єкта адміністративного проступку, навіть попри очевидний факт вчиненого протиправного діяння, адміністративна справа взагалі не порушується. Чинне законодавство про адміністративну відповідальність допускає можливість здійснення спеціальних заходів, спрямованих на встановлення особи порушника, але тільки в тих випадках, коли таке встановлення не вимагає проведення складного комплексу слідчих дій та, відповідно, не передбачає значних часових і матеріальних затрат. Як правило, це відбувається лише при фізичній можливості затримати порушника на місці порушення, або ж за наявності певних ідентифікаційних даних (наприклад, реєстраційного номера транспортного засобу), достатніх для оперативного і точного встановлення особи.

Таким чином, з'ясування особи порушника $є$ не тільки обов'язковим елементом кваліфікації, а й необхідною умовою відкриття провадження в справі. Аналіз правозастосовної практики свідчить про те, що більшість проблемних аспектів встановлення суб'єкта адміністративного проступку на автомобільному транспорті пов'язані з аналізом його спеціальних ознак. В ході їх вивчення уповноважені суб'єкти кваліфікації допускають велику кількість помилок, які вкрай негативно відбиваються на перебігу адміністративного провадження, призводять до прийняття необгрунтованих рішень та великої кількості скарг на рішення в справах про адміністративні проступки.

Аналіз останніх досягнень і публікацій. 3 огляду на свою актуальність, проблематика суб'єкта адміністративних проступків на автомобільному транспорті привертає увагу багатьох галузевих дослідників. В даному аспекті особливий теоретичний $\mathrm{i}$ прикладний інтерес становлять наукові праці А.В. Гуржій, Т.О. Гуржія, В.В. Доненка, В.К. Колпакова та інших $[1 ; 2 ; 3 ; 4 ; 5 ; 6]$. Разом $з$ тим, стрімкий розвиток адміністративно-деліктного законодавства - з одного боку, та масштабне впровадження цифрових засобів фіксації адміністративних проступків на транспорті - з іншого, актуалізували широке коло нових проблем встановлення спеціальних ознак суб'єкта адміністративних проступків на автомобільному транспорті.

Метою статті $\boldsymbol{\epsilon}$ формування комплексу законодавчих пропозицій і методичних рекомендацій, які спрямовані на мінімізацію помилок суб'єктів кваліфікації при встановленні спеціальних ознак суб'єкта адміністративних проступків на автомобільному транспорті.

Як відомо, суб’єкт адміністративного проступку - це не абстрактне явище. Це реально наявна фізична або юридична особа, фактичними діями (бездіяльністю) 
якої було порушено конкретні норми права та створено реальну небезпеку для суспільних відносин. Разом з тим, як справедливо зазначається в науковій літературі, склад правопорушення містить не загальний опис реальної людини, а охоплює низку визначених ознак, котрі дозволяють здійснити соціальну та юридичну оцінку особи порушника [7, с. 109; 8, с. 32-33].

Такі ознаки суб'єкта адміністративних правопорушень заведено поділяти на загальні та спеціальні. Загальні ознаки (вік і осудність) - характеризують особу порушника, як таку, що в силу свого рівня психологічного розвитку та поточного (на момент вчинення делікту) психічного стану, є здатною усвідомлювати протиправний та антисоціальний характер своєї поведінки, а також нести за свої дії адміністративну відповідальність.

У свою чергу, спеціальні ознаки - це ознаки, котрі включаються до складів лише окремих правопорушень, вчинення яких нерозривно пов'язане з певним правовим, професійним, фізичним, поведінковим або іншим статусом особи. Вони обов'язково вказуються у змісті законодавчих положень про відповідальність за конкретні проступки й є обов'язковими для встановлення при їх кваліфікації. Суб'єктів, які характеризуються такими ознаками, у вітчизняній теорії адміністративного права іменують спеціальними суб'єктами.

Аналіз чинного законодавства дозволяє виділити наступні категорії спеціальних суб’єктів адміністративних проступків на автомобільному транспорті:

1) водій автотранспортного засобу, тобто особа, яка керує автотранспортним засобом та має посвідчення водія (посвідчення тракториста-машиніста, тимчасовий дозвіл на право керування транспортним засобом, тимчасовий талон на право керування транспортним засобом) відповідної категорії. Водієм також вважається особа, яка навчає керування транспортним засобом, перебуваючи безпосередньо в ньому [9].

Значна частина, так званих, «водійських» порушень можуть бути вчинені водіями будь-яких категорій. Але в багатьох випадках спеціальним суб'єктом адміністративного проступку на автомобільному транспорті є водій визначеної категорії. При цьому для кваліфікації окремих адміністративних проступків потрібно констатувати наявність в особи не тільки права керування транспортними засобами, а й певного водійського стажу. Наприклад, суб'єктами перевезення небезпечних вантажів, а отже й суб'єктами порушення відповідних правил (тобто, адміністративних проступків, передбачених ч. 3 ст. 123-3 та ст. 132-1 Кодексу України про адміністративні правопорушення (далі - КУпАП), можуть бути лише: а) особи, які останні три роки працюють водіями транспортних засобів відповідної категорії; б) військовослужбовці строкової військової служби, особи рядового та молодшого начальницького складу служби цивільного захисту, які пройшли спеціальну підготовку та стажування протягом шести місяців;

2 ) власник (належний користувач) транспортного засобу. Відповідно до чинного законодавства, суб'єктами порушень Правил дорожнього руху, які зафіксовані в автоматичному режимі або в режимі фотографування (відеозапису), можуть бути: - фізична особа, на яку зареєстровано транспортний засіб; - керівник юридичної особи, за якою зареєстровано транспортний засіб, або особа, що виконує його повноваження; - належний користувач транспортного засобу. 
Варто зазначити, що у випадках автоматичної, фото або відео- фіксації порушень Правил дорожнього руху особа суб'єкта відповідальності за його вчинення встановлюється за допомогою відповідних державних реєстрів: Єдиного державного реєстру МВС України (в КУпАП - «Єдиний державний реєстр транспортних засобів»), а також Єдиного державного реєстру юридичних осіб, фізичних осіб-підприємців і громадських формувань.

Якщо в ході кваліфікації було з'ясовано, що Єдиний державний реєстр МВС України містить дані й про власника транспортного засобу, й про його належного користувача, то суб'єктом відповідальності за відповідне порушення визнається останній. Якщо ж транспортний засіб зареєстрований за юридичною особою, а в Єдиному державному реєстрі юридичних осіб, фізичних осіб-підприємців і громадських формувань відсутні дані про керівника такої особи, адміністративне стягнення накладається на особу, котра виконує його повноваження;

3) особа, яка ввезла транспортний засіб на територію України. Згідно зі ст. 122 КУпАП, якщо автотранспортний засіб був зареєстрований за кордоном (а отже він не підлягає державній реєстрації в Україні й дані про нього в Єдиному державному реєстрі МВС України відсутні), до адміністративної відповідальності за порушення Правил дорожнього руху, зафіксовані в автоматичному режимі або в режимі фотографування (відеозапису), до адміністративної відповідальності притягується особа, яка ввезла такий транспортний засіб на територію України [10]. Інформація про таких осіб міститься в базі даних «Відомості про осіб, які перетнули державний кордон України», яка перебуває у віданні Адміністрації Державної прикордонної служби України та є складовою інтегрованої міжвідомчої інформаційно-телекомунікаційної системи щодо контролю осіб, транспортних засобів та вантажів, які перетинають державний кордон «Аркан» [11];

4) посадова особа, відповідальна за технічний стан, обладнання та експлуатацію транспортних засобів. Відповідно до ст.ст. 10 та 11 Закону України «Про дорожній рух", посади фахівців з безпеки дорожнього руху обов'язково створюються: а) в автотранспортних підприємствах з 15 та більше одиницями транспорту (за умови якщо відповідні транспортні засоби (далі - т/з) дислокуються в одному населеному пункті); б) в центральних органах виконавчої влади, об'єднаннях, підприємствах та організаціях, де кількість осіб, зайнятих експлуатацією т/з, перевищує 50 чоловік [12].

На особу, яка обіймає посаду фахівця з безпеки дорожнього руху, покладено широке коло обов’язків, в тому числі: «<...> забезпечувати належний технічний стан транспортних засобів і дотримання екологічних вимог їх експлуатації; не допускати до керування транспортними засобами осіб, які не мають права на керування т/з відповідної категорії, не пройшли у встановлений строк медичного огляду, перебувають в стані алкогольного, наркотичного чи іншого сп'яніння або під впливом лікарських препаратів, що знижують їх увагу та швидкість реакції; не випускати на лінію т/3, технічний стан яких не відповідає вимогам державних стандартів, правил дорожнього руху, а також якщо вони не зареєстровані у встановленому порядку, переобладнані з порушенням вимог законодавства або не пройшли обов’язкового технічного контролю» [12]. Невиконання або неналежне виконання 
цих обов'язків тягне за собою адміністративну відповідальність за ст.ст. 128, 129 та 132-1 КУпАП;

5) посадова особа, відповідальна за утримання автолобільних доріг, вулиць та інших об'єктів дорожньої інфраструктури є суб'єктом адміністративних проступків, передбачених ст.ст. 128-1, 139 та 140 КУпАП. Слід зазначити, що встановлення конкретної посадової особи, винної у вчиненні зазначених правопорушень, великою мірою залежить від виду та розташування автомобільної дороги, на якій таке порушення було скоєно. Відповідно до Закону України «Про автомобільні дороги" (ст. 5), всі автомобільні дороги поділяються на чотири типи: 1) дороги загального користування; 2) вулиці та дороги населених пунктів; 3) відомчі (технологічні) дороги; 4) автомобільні дороги на приватних територіях [12]. Відповідальність за стан кожного типу автомобільних доріг несуть їх балансоутримувачі.

Для автомобільних доріг загального користування такими є Державне агентство автомобільних доріг України (Укравтодор) та його регіональні підрозділи (служби автомобільних доріг в областях і м. Києві).

Дороги та вулиці міст та інших населених пунктів перебувають у віданні органів місцевого самоврядування і $є$ комунальною власністю. Зважаючи на це, відповідальність за стан їх утримання несуть міські, сільські та селищні ради.

До відомчих (технологічних) автодоріг належать внутрішньогосподарські технологічні дороги, які перебувають у власності юридичних або фізичних осіб. Відповідно за якість проектування, будівництва, реконструкції, ремонту та безпеку експлуатації таких доріг відповідають їх власники.

I, нарешті, відповідальність за стан доріг на приватних територіях несуть власники таких територій (фізичні або юридичні особи приватного права), а у разі передачі ними дороги в державну чи комунальну власність на підставі ст. 25 Закону України «Про автомобільні дороги», - відповідний регіональний підрозділ Укравтодору або місцева (міська, сільська, селищна) рада [13].

Варто додати, що у випадках порушення правил, норм і стандартів безпеки дорожнього руху при утриманні залізничних переїздів (ч. 1 ст. 140 КУпАП) їх суб'єктами виступають посадові особи АТ «Укрзалізниця» (як балансоутримувача магістральних залізничних колій) або посадові особи підприємств, установ, організацій, котрі є власниками під’їзних колій [14].

Важливими моментами при встановленні суб'єкта відповідальності за порушення правил утримання автомобільних доріг і вулиць є: по-перше, чітке визначення юридичної особи, у віданні якої перебуває відповідна ділянка або об’єкт дорожньої інфраструктури; по-друге, ретельний аналіз функцій і повноважень посадових осіб з метою встановлення причинно-наслідкового зв'язку між діями (бездіяльністю) конкретного посадовця та суспільно-небезпечними наслідками порушення.

Обидва вказані моменти далеко не завжди належним чином враховуються уповноваженими суб'єктами кваліфікації. При цьому на практиці найбільші труднощі викликаєпитанняпроте, хтосамеповиненнестивідповідальністьзапорушення правил утримання автомобільних доріг і вулиць: безпосередньо орган влади (служба Укравтодору, місцева рада) чи підпорядковане йому дорожньо-експлуатаційне 
підприємство (державне, комунальне), котре є балансоутримувачем конкретної дороги/вулиці.

У розв'язанні цього питання суди всіх інстанцій, в тому числі Верховний Суд України, не демонструють чіткої, послідовної позиції. Зокрема, Верховний Суд України, розглянувши справу № 760/8191/15-ц від 07 листопада 2016 р. (у фабулі цієї справи йшлося про ДТП внаслідок наїзду автомобіля на незакріплену кришку каналізаційного люку), погодився з висновком суду апеляційної інстанції про те, що відповідальність за скоєне має нести балансоутримувач вулиці - Комунальне підприємство «Шляхово-експлуатаційне управління по ремонту та утриманню автомобільних шляхів та споруд на них Солом'янського району м. Києва».

В іншій справі з аналогічною фабулою (справа № 373/1281/16-ц від 15 травня 2018 р.) Верховний Суд України залишив у силі ухвалу суду апеляційної інстанції про стягнення заподіяних збитків з Переяслав-Хмельницької міської ради Київської області. При цьому правова позиція Переяслав-Хмельницької міської ради грунтувалася на тому, що виходячи з попередніх судових рішень у подібних справах, відповідальність за скоєне повинно нести Комунальне підприємство «Переяслав-Хмельницьке виробниче управління комунального господарства», яке виступає балансоутримувачем відповідної вулиці.

I хоча в обох зазначених рішеннях йдеться про розгляд цивільних справ стосовно відшкодування заподіяних матеріальних збитків, вони вельми наочно ілюструють проблему встановлення посадової особи, відповідальної за порушення правил утримання автомобільних доріг і вулиць, як суб'єкта адміністративного проступку. Адже встановити таку особу можна лише з'ясувавши, який саме орган (підприємство, організація) несе безпосередню відповідальність за безпечні умови руху на конкретній ділянці дороги (вулиці);

6 ) інші посадові особи. Нерідко у якості спеціального суб'єкта адміністративних проступків на автомобільному транспорті законодавець визначає посадову особу як таку (тобто, без конкретизації її організаційної належності або характеру здійснюваних повноважень). Утім, з контексту відповідних положень КУпАП недвозначно випливає, що суб'єктом відповідних проступків може бути не будь-яка посадова особа взагалі, а посадова особа суб'єкта (органу, підприємства), який спеціалізується на транспортній діяльності.

Зокрема, суб'єктами порушення порядку видачі документа про технічну справність транспортного засобу (ч. 1, 2 ст. 127-1 КУпАП) є посадові особи підприємств, інформація про яких внесена до Реєстру суб'єктів проведення обов'язкового технічного контролю транспортних засобів та які мають у власності/користуванні необхідне устаткування для перевірки технічного стану т/з на відповідність вимогам безпеки дорожнього руху й охорони навколишнього природного середовища.

Суб'єктом порушення порядку укладення договору обов'язкового страхування цивільно-правової відповідальності власників наземних транспортних засобів $\mathrm{\epsilon}$ посадова особа страховика, тобто фінансової установи (товариства), яка має ліцензію на здійснення страхової діяльності.

Суб'єктами порушень правил надання послуг з перевезення пасажирів (ч. 1, 2 та 5 ст. 133-1 КУпАП) визнаються посадові особи підприємств, які провадять госпо- 
дарську діяльність з внутрішніх та/або міжнародних перевезень пасажирів автобусами, а також посадові особи підприємств, атестованих, як власники автостанцій.

I лише у разі порушення правил, норм і стандартів під час виготовлення та ремонту транспортних засобів і деталей до них (ч. 1 ст. 128-1 КУПАП), суб'єктами адміністративної відповідальності можуть виступати посадові особи будь-яких підприємств, установ та організацій, незалежно від форми власності чи профілю діяльності (після скасування у 2010 р. обов'язково ліцензування виробництва автомобілів та автобусів така діяльність може здійснюватись будь-яким суб’єктом господарювання);

7 ) зеллекористувачі ділянок, прилеглих до автолобільних шляхів. Єдині правила ремонту та утримання автомобільних доріг, вулиць, залізничних переїздів, користування ними та охорони, затверджені Постановою Кабінету Міністрів України від 30 березня 1994 р. № 198, покладають на власників та користувачів земельних ділянок, які межують зі смугою відведення заміських автодоріг або червоними лініями доріг і вулиць населених пунктів, обов'язки: утримувати в належному стані виїзди з цих ділянок; запобігати винесенню на дорожні об'єкти землі, каміння та інших матеріалів, сміття; установлювати та утримувати в справному стані огорожі тощо [15]. Невиконання зазначених обов' язків тягне за собою відповідальність за ст. 142 КУпАП «Порушення землекористувачами правил утримання ділянок, прилеглих до автомобільних шляхів» .

В аспекті правового визначення та встановлення суб'єкта адміністративних проступків, передбачених ст. 142 КУпАП, слід звернути увагу на таку проблему. Попри те, що чинне законодавство закріплює обов'язки по утриманню придорожніх ділянок і об'єктів за різними категоріями суб'єктів (власниками земельних ділянок та землекористувачами), до адміністративної відповідальності за їх порушення (невиконання, неналежне виконання) можуть притягуватись тільки землекористувачі, тобто: «юридичні та фізичні особи (резиденти та нерезиденти), яким відповідно до закону надані у користування земельні ділянки державної та комунальної власності, у тому числі на умовах оренди» [16].

Більш того, із санкції ст. 142 КУпАП випливає, що суб’єктами порушення правил утримання ділянок, прилеглих до автомобільних шляхів, можуть бути не всі користувачі таких ділянок. Запровадивши відповідальність громадян і посадових осіб органів (підприємств, організацій), законодавець не передбачив ії для фізичних осіб - підприємців. Між тим, сьогодні значна частина земель, прилеглих до автомобільних доріг (передусім, у населених пунктах) перебуває в користуванні саме цієї категорії суб’єктів підприємницької діяльності.

3 огляду на це, видається доцільним внесення змін до ст. 142 КУпАП з метою поширення іiї дії на фізичних осіб-підприємців, а також на посадових осіб органів (підприємств, установ, організацій), котрі є власниками земельних ділянок, прилеглих до автомобільних шляхів;

8) консультанти (уповноважені) з питань безпеки перевезення небезпечних вантажів. Відповідно до п. 1.8.3.1 Додатку А Європейської Угоди про міжнародне дорожнє перевезення небезпечних вантажів (дивись Закон України від 02 березня 2000 р. № 1511-III «Про приєднання України до Європейської Угоди про міжнародне 
дорожне перевезення небезпечних вантажів (ДОПНВ)», кожне підприємство, діяльність якого включає автомобільне перевезення небезпечних вантажів або пов'язані з ним операції щодо пакування, навантаження, наповнення або розвантаження, призначає одного чи декількох консультантів з питань безпеки перевезення небезпечних вантажів, завдання яких полягає в сприянні запобіганню небезпеці для людей, майна та довкілля, властивій такого роду діяльності [17].

Невиконання або неналежне виконання функцій консультанта є підставою для притягнення консультанта з питань безпеки перевезення небезпечних вантажів до відповідальності за вчинення адміністративного проступку, передбаченого ст. 132-1 КУпАП. При цьому, суб'єкт кваліфікації обов'язково повинен переконатись у тому, що причиною порушення стало невиконання (неналежне виконання) функцій саме консультанта з безпеки перевезення небезпечних вантажів, а не іншої посадової особи установи (підприємства, організації). Адже в юрисдикційній практиці відомі непоодинокі випадки, коли за порушення, допущені консультантами 3 безпеки перевезення небезпечних вантажів, до відповідальності притягувались особи, відповідальні за випуск транспортного засобу на лінію, і навпаки [1, с. 116].

9 ) інспектори з паркування. Наприкінці 2017 р. в Україні було здійснено масштабну реформу у сфері паркування транспортних засобів. Поряд із затвердженням вимог щодо облаштування паркувальних майданчиків та впорядкуванням механізмів оплати послуг паркування, дана реформа передбачила створення при виконавчих органах сільських, селищних, міських рад інспекційних підрозділів 3 питань паркування. Працівникам таких підрозділів - інспекторам з паркування було надано широкі юрисдикційні, повноваження, зокрема, щодо фіксації порушень правил паркування, а також правил зупинки/стоянки транспортних засобів в межах населеного пункту, складання відповідних адміністративних протоколів, здійснення заходів адміністративного забезпечення (тимчасової евакуації транспортних засобів) та накладення адміністративних стягнень за адміністративні проступки, передбачені ч. 1, 3 ст. 122 та ч. 1, 2 ст. 152-1 КУпАП.

Водночас, з метою запобігання можливим зловживанням з боку інспекторів законодавець доповнив чинний КУпАП статтею 127-2, котра встановила їх відповідальність за прийняття готівкових коштів як оплати послуг з паркування транспортних засобів та/або оплати штрафів, накладених на місці вчинення правопорушення (ч. 2), а також за повторне (протягом року) вчинення цього порушення (ч. 3) [18].

Наразі стала практика юрисдикційної діяльності, а тим більше - практика притягнення інспекторів з паркування до адміністративної відповідальності, в Україні поки не напрацьована. Проте, вже на цьому етапі доводиться говорити про очевидні вади нинішньої редакції ч. 2 ст. 127-2 КУпАП. Адже ні чинне законодавство, ані положення про інспекторів з паркування, які приймаються місцевими радами, не покладають на інспекторів функцію стягнення оплати послуг з паркування транспортних засобів. Відповідно, прийняття ними готівкових коштів як оплати за паркування не може вважатися порушенням встановленого порядку грошових розрахунків, а являє собою випадок прийняття неправомірної вигоди службовою особою, тобто злочин, передбачений ч. 1 ст. 368 Кримінального кодексу (далі - КК) 
України. За таких обставин адміністративна деліктизація означеного діяння позбавлена прикладного сенсу. Оскільки конкуренцію між нормами адміністративно-деліктного та кримінального права завжди «виграє» остання, відповідне положення КУпАП неможливо застосувати на практиці. Зважаючи на це, видається доцільним вилучити його зі змісту ч. 2 ст. 127-2 КУпАП;

10) керівник суб'єкта господарювання є суб'єктом порушення порядку тимчасового затримання транспортних засобів та їх зберігання (ч. 1 ст. 127-2 КУпАП). Відповідно до чинного законодавства, тимчасове затримання транспортного засобу здійснює офіцер поліції або інспектор з паркування шляхом його доставки на спеціальний майданчик чи стоянку Національної поліції, її територіальних органів, а також підприємств, установ та організацій, з якими територіальними органами Національної поліції укладено договори $[19 ; 20]$. Безпосереднє доправлення транспортного засобу на спеціальний майданчик або стоянку здійснюється за допомогою спеціальних автомобілів-евакуаторів суб'єктами господарювання (підприємствами, установами, організаціями, фізичними особами-підприємцями), які спеціалізуються на транспортуванні транспортних засобів, і з якими територіальні органи поліції/ органи місцевого самоврядування також уклали відповідний договір.

Саме ці суб'єкти (власники евакуаторів, майданчиків і стоянок) несуть матеріальну відповідальність за шкоду, заподіяну транспортному засобу під час його транспортування та зберігання. I саме вони (точніше, їх керівники) є відповідальними за порушення встановленого порядку транспортування/зберігання транспортних засобів, в тому числі - за провадження такої діяльності без відповідного поліса обов'язкового страхування цивільної відповідальності;

11) фізичні особи-підприємиі (громадяни-суб’єкти господарської (підприємницької) діяльності) можуть виступати суб'єктами адміністративних проступків, передбачених ст.ст. 127-2, 128, 129, 132-1, 133-1, 133-2, 139 та 140 КУпАП. Аналіз вказаних статей змушує констатувати певну термінологічну розбіжність. Якщо суб'єкти адміністративних проступків, передбачених ст.ст. 128, 129, 132-1, 139 та 140 КУпАП визначені як «громадяни-суб'єкти господарської діяльності», то в ст.ст. 133-1 і 133-2 КУпАП вони іменуються «громадяни-суб'єкти підприємницької діяльності». 3 метою упорядкування поняттевого апарату КУпАП дана розбіжність має бути усунута.

Зауважимо, що в господарському і цивільному законодавстві жоден з цих термінів не використовується. Водночас, Господарський кодекс України (ч. 2 ст. 55) визначає дану категорію суб’єктів, як «громадяни України, іноземці та особи без громадянства, які здійснюють господарську діяльність та зареєстровані відповідно до закону як підприємці». У свою чергу, Цивільний кодекс України (Глава 5) та Закон України «Про державну реєстрацію юридичних осіб, фізичних осіб-підприємців та громадських формувань» оперують терміном «фізична особа-підприємець». На наш погляд, саме цей термін найбільш точно відбиває офіційний правий статус громадян, які займаються підприємництвом без створення юридичної особи, а отже саме він повинен знайти відбиття в кореспондуючих положеннях КУпАП.

Висновки. Підсумовуючи викладене можемо констатувати, що практичне встановлення суб'єкта адміністративних проступків на автомобільному транспорті 
супроводжується багатьма проблемами, які обумовлюють помилки при кваліфікації, неправильне застосування адміністративно-деліктних норм, виникнення юридичних конфліктів. Це, зокрема, і недостатній професійний рівень суб'єктів кваліфікації, і брак методичного забезпечення, і слабке технічне/програмне оснащення (особливо, це стосується міжвідомчого обміну даними з електронних реєстрів), і багато інших. Але, безумовно, головна проблема криється в площині законодавства.

Вади законодавчого регулювання суттєво утруднюють кваліфікацію правопорушень, «фрагментують» захист галузевих відносин, знижують загальну ефективність інституту адміністративної відповідальності. Від їх якнайшвидшого усунення залежить не тільки захищеність відповідних суспільних відносин, а й фактичний стан транспортної безпеки. У світлі викладеного постає необхідність удосконалення ряду положень КУпАП в частині опису суб'єктів адміністративних проступків на автомобільному транспорті. 3 цією метою необхідно:

- виключити ч. 2 зі змісту ст. 127-2 КУпАП;

- у тексті КУпАП (зокрема, у ст.ст. 128, 129, 132-1, 133-1, 133-2, 139 та 140) слова «громадянин-суб'єкт господарської діяльності» та «громадянин-суб'єкт підприємницької діяльності» у всіх відмінках замінити словами «фізична особа-підприємець»;

- статтю 142 КУпАП «Порушення землекористувачами правил утримання ділянок, прилеглих до автомобільних шляхів» викласти в такій редакції:

Порушення правил утримання ділянок, прилеглих до смуги відводу автомобільних шляхів загальнодержавного, республіканського і місцевого значення, обов'язків по очищенню тротуарів, пішохідних доріжок у межах закріплених за ними ділянок, обладнанню і ремонту переїзних містків та їх очищенню, а також по утриманню у справному стані під'їздів до автомобільних шляхів загального користування - тягне за собою попередження або накладення штрафу на громадян від одного до трьох неоподатковуваних мінімумів доходів громадян і попередження або накладення штрафу на посадових осіб, фізичних осіб-підприємиів - від трьох до семи неоподатковуваних мінімумів доходів громадян.

\section{Jimepamypa}

1. Гуржій А.В. Проблеми встановлення суб’єкта порушень правил перевезення небезпечних, великовагових і великогабаритних вантажів у процесі адміністративно-правової кваліфікації. Вісник Запорізького наиіонального університету. Серія «Юридичні науки». 2012. № 1. Ч. 2. С. 111-117.

2. Гуржій Т.О. Адміністративно-правові проблеми забезпечення безпеки дорожнього руху в Україні : монографія. Харків : Тимченко, 2010. 480 с.

3. Гуржій Т.О. Встановлення ознак суб'єкта адміністративного делікту в процесі адміністративноправової кваліфікації. Право України. 2003. № 5. С. 75-79.

4. Гуржій Т.О. Актуальні проблеми законодавчого регулювання адміністративно-деліктних відносин у сфері безпеки дорожнього руху. Право України. 2009. № 3. С.90-94.

5. Керування транспортом у стані сп'яніння : адміністративно-деліктні проблеми : монографія / В.В. Доненко, В.К. Колпаков. Дніпропетровськ : Юридична академія, 2003. 196 с.

6. Колпаков В.К. Порушення правил дорожнього руху : колізійність новел і правове регулювання : монографія / В.К. Колпаков, О.В. Черновський, В.В. Гордєєв. Чернівці : Чернівецький нац. ун-т, 2010. $328 \mathrm{c}$.

7. Гуржій Т.О. До питання про суб’єкта адміністративного делікту. Вісник Прокуратури. 2007. № 10. С. 109-112. 
8. Шестак Л. До питання про ознаки суб'єкта адміністративного правопорушення. Підприємниитво, господарство і право. 2013. № 9. С. 32-34.

9. Про Правила дорожнього руху : Постанова Кабінету Міністрів України від 10 жовтня 2001 р. № 1306. Офіщійний вісник України. 2001. № 41. Ст. 1852.

10. Кодекс України про адміністративні правопорушення. Відомості Верховної Ради Української РСР. 1984. Дод. до № 51. Ст. 1122.

11. Про затвердження Положення про базу даних «Відомості про осіб, які перетнули державний кордон України» : Наказ Адміністрації державної прикордонної служби України від 25 червня 2007 р. № 472. Офіційний вісник України. 2007. № 50. Ст. 2047.

12. Про дорожній рух : Закон України. Відомості Верховної Ради України. 1993. № 31. Ст. 338.

13. Про автомобільні дороги : Закон України від 08 вересня 2005p. № 2862-IV. Офіційний вісник України. 2005. № 40. Ст. 2534.

14. Про залізничний транспорт : Закон України від 04 липня 1996p. № 273/96-ВР. Відомості Верховної Ради України. 1996. № 40. Ст. 183.

15. Про затвердження Єдиних правил ремонту і утримання автомобільних доріг, вулиць, залізничних переїздів, користування ними та охорони : Постанова Кабінету Міністрів України від 30 березня 1994 р. № 198. Офіційний сайт Верховної Ради України. URL: https://zakon.rada.gov.ua/ laws/show/ 198-94-\% D0\% BF

16. Податковий Кодекс України від 02 грудня 2010 p. № 2755-VI. Офіиійний вісник України. 2010. № 92. Т.1. Ст. 3248.

17. European Agreement Concerning the International Carriage of Dangerous Goods by Road. Vol. 1 . United Nations : New York and Geneva, 2016.614 p.

18. Про внесення змін до деяких законодавчих актів України щодо реформування сфери паркування транспортних засобів : Закон України від 21 грудня 2017 р. № 2262-VIII. Офіційний вісник України. 2018. № 28. Ст. 995.

19. Про затвердження Порядку тимчасового затримання працівниками уповноважених підрозділів Національної поліції транспортних засобів та їх зберігання : Постанова Кабінету Міністрів України від 17 грудня 2008 р. № 1102. Офіційний вісник України. 2008. № 98. Ст. 3240.

20. Про затвердження Порядку тимчасового затримання інспекторами з паркування транспортних засобів та їх зберігання : Постанова Кабінету Міністрів України від 14 листопада 2018p. № 990. Офіційний вісник України. 2018. № 95. Ст. 3134.

\section{Анотація}

Нефедова А. В. Спеціальні ознаки суб’єкта адміністративних проступків на автомобільному транспорті. - Стаття.

Стаття висвітлює питання встановлення спеціальних ознак суб'єкта адміністративних проступків на автомобільному транспорті в ході їх кваліфікації.

Ключові слова: адміністративна відповідальність, адміністративний проступок, кваліфікація адміністративних проступків, суб’єкт адміністративного проступку.

\section{Аннотация}

Нефедова A. В. Специальные признаки субъекта административных проступков на автомобильном транспорте. - Статья.

Статья освещает вопросы установления признаков субъекта административных проступков на автомобильном транспорте в ходе их квалификации.

Ключевые слова: административная ответственность, административный проступок, квалификация административных проступков, субъект административного проступка.

\section{Summary}

Nefedova A. V. Special features of the subject of administrative offenses on road transport. - Article.

The article covers the issues of establishing the signs of a subject of administrative misconduct on road transport during their qualification.

Key words: administrative responsibility, administrative offense, qualification of administrative offenses, subject of administrative offense. 